\title{
Does the Modern General Theory of State and Law Remain a Fundamental, Methodological Juridical Science?
}

\author{
Vladimir Valentinovich Kozhevnikov \\ Department of Theory and History of State and Law, Omsk State University Dostoevsky, Omsk, Russia \\ kta6973@rambler.ru
}

\section{Abstract}

This scientific article is devoted to the general theory of state and law as a fundamental, methodological legal science at all stages of its development. The article substantiates the position according to which its belittling both at the theoretical and at the practical levels is unreasonable.
Keywords

theory of state and law; methodological science; belittling the status of science; ideology of Marxism-Leninism; legal education

\section{Introduction}

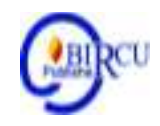

We believe that the given title of this scientific article in the form of a question is quite logical and reasonable against the background of those theoretical propositions that assert the opposite. So, a team of rather authoritative theoretical scientists, showing inconsistency, because earlier they justified a completely different position, considering the issue of the place of the theory of state and law in the system of not social sciences, as the authors believe, but legal, literally write that "the history of the state and law is basic (hereinafter we have highlighted it - Vladimir Valentinovich Kozhevnikov) in relation to the theory of state and law" [1].

A negative assessment of the theory of state and law, the belittling of its status for jurisprudence, also takes place in the position of another group of scientists who note that the theory of state and law in modern conditions performs the function of serving the official ideology, and the concepts of "human rights", "rule of law" represent such the same ideological clichés, which used to be "the state of the whole people" or "socialist democracy", writes about that "the traditional for the theory of state and law, methodological and partly futurological functions are now performed by branch sciences, in connection with which the theory is losing its significance as a fundamental, generalizing legal science" [2].

One of the authors of this very unreasonable point of view, Roman Anatolyevich Romashov, at one time in one of his works emphasized that "the theory of state and law is a fundamental legal science, and then, again emphasizing that this science occupies an important place in the system domestic legal education [3], backs down, saying that there are different points of view on this issue, often contradictory and sometimes mutually exclusive, believes the following: "This circumstance, on the one hand, testifies to the pluralism of modern Russian jurisprudence, and on the other - is an indicator of the uncertainty of targets, which is guided in their activities by representatives of domestic legal science and education "[3]. 


\section{Research Methods}

When preparing a scientific article, the following methods were used:

\section{General Philosophical (Dialectical-Materialistic)}

General philosophical (dialectical-materialistic), which is used in all social sciences;

1. General scientific (analysis and synthesis, logical and historical, comparisons, abstractions, etc.), which are used not only by the theory of state and law, but also by other social sciences;

2. Special methods (philological, cybernetic, psychological, etc.), developed by special sciences and widely used for the knowledge of state and legal phenomena;

3. Private scientific (formal legal, interpretation of law, etc.), which are developed by the theory of state and law.

\section{Results and Discussion}

\subsection{Deideologization of the Modern Theory of State and Law}

Scientists stubbornly refuse to see the process of the so-called de-ideologization of the modern theory of state and law, which is analyzed by Evgeny Ivanovich Temnov. In particular, the author believes that "the problem of methodological renewal, faced by political and legal science, requires a purely creative and realistic approach from the educational process, a critical assessment of the achieved, attentive and responsible perception of the new. Rejection of dogmatism, revision of the available theoretical baggage presuppose the constructiveness of the methodological premises themselves, interaction in a number of cases with the theoretical constructions of opponents "[4].

It is difficult to agree with scholars who belittle the status of the general theory of state and law, which, in their opinion, performs "the function of serving the official ideology" This is despite the fact that our society, unfortunately, does not have a clear andmeaningful national state-legal ideology, ignoring such an unwritten law: "Consciousness, including legal, does not tolerate emptiness, some, often far from the best, the system of views will always fill him." Tatiana Vitalievna Sinyukova, developing these provisions, emphasizes that as a result of mechanical deideologization, a most dangerous situation has arisen, even in comparison with the consequences of the economic crisis: an increasing feeling of spiritual emptiness, meaninglessness, hopelessness, temporality of everything that is happening, which visibly covers more and more new layers of the population. ... From the author's point of view, "in our" de-ideologized "consciousness there is a growing tendency towards social primitivism, mass aberrations (ie, delusions Vladimir Kozhevnikov), the loss of the already weak immunities from charismatic, nationalist populism" [5]. At one time, Daniil Alexandrovich Granin wrote the following: "Recently, the intelligentsia had the idea of opposing the regime, the monstrous Soviet ideology. Ideology is gone, and there is no one to resist "[6]. It seems to be quite appropriate here to emphasize that the ideal is like a beacon that directs individual and social movement in the right direction. This also applies to legal ideals. In legal life, the latter are an indispensable component. Now in modern Russia, perhaps the highest legal ideal is the rule of law. This is reflected in Article 1 of the Constitution of the Russian Federation, where, however, it is not about an ideal, but an already accomplished fact of Russian reality. But it is quite obvious that this is not the case. The rule of law is only an ideal that expresses the official legal position of our state. As for the issue of the Russian legal ideal, here, as Rustam Suleimanovich Bainiyazov emphasizes, that, as life shows, the 
rule of law has not become a national ideal (not to mention practice) for Russian citizens. On the contrary, in the minds of people about this there is disbelief, skepticism, apathy. The spiritual situation in Russia is such that the communist myth has long been debunked, the old "ideals" have been thrown away, but there are practically no new ones, and if there are, then those that are far from always adequate to the people's spirit [7].

It seems important to note that in science, the ideological aspects of legal science have been given more or less attention by legal scholars. Thus, Anisim Ivanovich Ekimov, highlighting two points of view in the context of this problem, emphasizes that according to the first position, it is necessary everywhere and everywhere to strive to de-ideologize scientific knowledge; there is a pure legal truth, independent of political interests, reflecting universal human values (recognized in a particular historical era or, on the contrary, unchanged at all times). According to the second - only properly ideologized knowledge can carry the truth; everything legal is fundamentally political, and the law itself is political. The concept of "ideology" is understood and evaluated in different ways: if the essence of ideology is that it is a set of certain paradigms, or ideologemes that serve the interests of a narrow circle of the elite, then legal science should, as far as possible, distance itself from it; if ideology is a collection of different kinds of ideas that more or less accurately reflect the essence of what is happening, then a different situation arises [8].

\subsection{Marxist-Leninist General Theory of State and Law}

Indeed, after 1917, jurisprudence was placed at the service of class interests, which, however, in practice were interpreted exclusively from the position of the administrativecommand elite. Entire sections of the theory of state and law (on the concept of state and law, on the functions of the state, etc.) were subjected to a radical revision. Instead of the ideological pluralism characteristic of the pre-revolutionary era, for many decades a monopoly on truth is being established exclusively for Marxism-Leninism. Accordingly, the theory of state and law began to be called nothing other than Marxist-Leninist.

At that time, only the views of pre-Marxist theoretical thought or concept based on the ideas of Karl Marx and Vladimir Ilyich Lenin were considered in a positive way. NonMarxist and anti-Marxist thought was either ignored or targeted because nothing positive was found in it. Modern Western state - legal systems were presented as hostile to the interests of the masses and incapable of ensuring the rights and interests of the general population.

Juridical science itself was proclaimed a party science, serving the interests of the proletariat. At the same time, it was asserted that the interests of the proletariat are the real interests of society. Therefore, everything that contradicts them objectively contradicts the interests of society.

The thesis that the state and law are subordinate to class interests was very widespread in the legal literature, and as the class division of society loses its meaning, the state and law will wither away. In the post-October period, the Soviet philosophical and legal thought in views of the state was unchanged: it was mainly focused on a more indepth disclosure of the class nature of the state in any of its manifestations, including socialist. The philosophical dictionary of that time stated that \&quot;the state is a political organization of the economically dominant class, with the goal of protecting the existing economic order and suppressing the resistance of other classes\&quot; [9].

It was recommended to search everywhere and everywhere for the class meaning of specific legal norms, specific state decisions. As a result of the "party" approach, legal science has lost an objective approach to the analysis of state and legal phenomena. First of all, this was expressed both in theory and in practice in the neglect of the interests of the 
individual, his rights. The independent status and significance of an individual, an individual as a subject of economics, law and politics were denied. A radical rejection of the individual in favor of the universal (social, collective) led to a comprehensive transformation of man into a living tool and auxiliary means of the universal whole, into a simple executor of the corresponding functions of a proletarian organized collectivity and socialist community, in a word, into an impersonal, ordinary, powerless "cog" of a single a huge machine of collective suppression, violence, power-centralized production, distribution and consumption. In this regard, it seems very appropriate to quote Daniil Aleksandrovich Granin's reflections in terms of criticism of Soviet science: "It is impossible to artificially stop the course of science. But the humanization of science is necessary. It became clear that the rational and logical development of science showed its inadequacy "[6]. Gradually, the Marxist dogma was established in Russian legal science. Dominance of the dogmatic concept, its monopoly position, which developed in the 1930s. and partly preserved to this day, has become a true tragedy of our jurisprudence. Soviet legal science turned into an ideological superstructure over the basis of the commandadministrative system, for which legislation served as a weapon in the struggle against the \&quot;internal and external\&quot; enemy, ensuring its dominant position, and achieving its own goals. The main duties of legal science were reduced to the analysis, commenting and apologetics of the law. The domestic law school gradually transformed into a school of dogmatism and deaf dogmatism. Here, it seems, the statement of Daniil Aleksandrovich Granin, who wrote that "pseudoscience was supposed to show everyone that ideology is higher than truth, that the interests of politics are higher than the interests of science" [6], are quite appropriate. Such a characteristic can be fully used in an objective assessment of the Marxist-Leninist general theory of state and law.

In this regard, Evgeny Ivanovich Temnov quite reasonably notes that "the ideologized positions of the researcher did not allow to fully trace the historical trajectory involvement in the spiritual orientations of the past. Monopoly, one-dimensionality and unidirectionality of the means of analysis did not take into account the contradictory, dual nature of the observed phenomena - law and the state. The content of the class approach gradually became ideological intolerance and closeness. ... The degree of democracy of theories was determined by the role that the thinker assigned to the working strata of the civilian population, the potential for the superiority of the tendencies and goals of the oppressed class over the manifestation of universal tendencies and goals "[4]. The scheme of the Marxist-Leninist approach was based on economic determinism: the state and law arise as a result of the emergence of private property, and its consequence is the split of society into antagonistic classes, the reconciliation of enmity between which is possible through the state and law. Marxism was entirely based on a formational approach. The doctrines of the legal and social state fell out of sight.

\subsection{Constructive-Critical Approach to the Marxist-Leninist Dogma}

Now, on the contrary, there is militant opposition and ruthless criticism of this approach. At the same time, it should be borne in mind that any theory, using its methods of cognition, carries grains of knowledge into the common piggy bank, allows you to deeper and more fully understand certain facets of the phenomena being studied. Apparently, today the most acceptable for jurisprudence is the so-called constructive critical approach to the assessment and analysis of past and present state - legal doctrines. The abovementioned fully applies to the Marxist - Leninist doctrine, which was subjected to severe criticism and even slander, including its former \&quot;ardent\&quot; supporters. The protracted systemic crisis in many countries called socialist, the vital need to 
overcome it, led to a sharply negative attitude towards Marxism - Leninism as a doctrine and socialism as a socio-political system. Noting that "until recently, any legal research was really "normatively"determined by the methodological principles of Marxist philosophy", which in the theory of cognition have now been pushed into the background by some researchers, Andrei Ivanovich Bryzgalov believes that "... to a certain extent they are also lost in legal science "[10].

However, science cannot go to extremes. There is no doubt that there is a lot of utopian and outdated in Marxism, but it contains provisions and conclusions that are of lasting importance (for example, ideas about collectivism, social justice, etc.). By the way, Russian theoretical scientists paid attention to this aspect of the problem.So, Evgeny Ivanovich Temnov, believing that for the study of difficult periods of historyor confrontation of ideological views, it is quite acceptable to take into account classinterest, emphasizes that "... such an approach should not turn into an exclusive and self-sufficient (as was the case in the Marxist-Leninist general theory of the state and prava-Vladimir Valentinovich Kozhevnikov) in the methodological arsenal of the research ".Reflecting on the methodology of cognition of state and legal reality, the author argues that "to see behind partisanship and class, more than one of the methods of cognition, a specific methodological approach and to raise it into a universal principle means ideologizing the means of scientific analysis, and, ultimately, and its results "[11].

Orest Vladimirovich Martyshin, reflecting on the concept of the state, notes that until the 90s of the last century, the Marxist-Leninist concept of the class nature of the state reigned supreme in our country, but then it began to be supplanted by the idea of the state as a good of civilization, serving not class, but universal interests. The author reveals the following tendency in the domestic legal sciences: one extreme - the Marxist interpretation of the state in the Soviet version, is replaced by another - a one-sided statement that the state serves the common good and only it, while the differences between what is and what is due are erased [12]. For example, Vladimir Aleksandrovich Chetvernin believes that "state power serves society as a whole and therefore expresses a general interest in ensuring the integrity and stability of the social system. But state power, in addition to the general interest, also expresses the interests and common interests of individuals - ensuring freedom, security and property "[13].

Taking into account the spread, including in the West, a more moderate and flexible approach, which boils down to the fact that the social content of the state is multifaceted, that in the activities and nature of each state, the interests of the ruling parties, the interests of some social groups and the general fortunately, the scientist quite reasonably asserts, substantiating the so-called realistic approach to the characteristics of each state, not excluding the modern Russian one, that "it is much wiser not to go to extremes, not to get carried away with either absolutization or uncompromising denial of Marxism, but to try to analyze the correlation of three groups of interests (rulers, classes, the whole society) in the activities of each state "[12].

It is not difficult to notice, and this is important in the context of this work, that despite the criticism of Marxism-Leninism, the overwhelming majority of modern theoretical scientists prefer the method of dialectical dialectics as a general philosophical (universal, worldview) method. It seems that this method has not lost its relevance in legal research. A number of other scientists agree with this statement. For example, the collective of authors of a textbook on philosophy of law believes that "the synthesizing qualities of philosophy of law are based on the fact that the core of philosophy as a methodological science is the unity of dialectics, logic and the theory of knowledge. This means, in generalized form, that the same system of laws and categories in dialectics acts 
as the principles of cognition of the objective world, in the theory of knowledge, as a means of solving specific cognitive problems, and in logic, as a form of scientific thinking "[14].

Viktor Mikhailovich Korelsky directly categorically declares that "our national science is characterized by an orientation toward a materialistic approach, according to which the deep essential aspects of the state and law are ultimately predetermined by the economy, by the existing forms of property. The materialistic approach allows us to trace the connection between the state and law with real processes and explore their possibilities for strengthening the material foundations and increasing the economic potential of society. \&quot; According to the scientist, "the philosophical basis of the theory of state andlaw is the dialectical method, that is, the doctrine of the most general regular connections of the development of being and consciousness" [15]. Recognizing that the method of dialectical and historical materialism made a huge contribution to the knowledge of political and legal reality, Vyacheslav Nikolayevich Zhukov in his scientific work, which for some unknown reason he called a textbook, writes that "at present, the state and law in development, historically, in the unity of the political, spiritual and economic life of society based on public practice as a criterion of truth (the main, but not the only one - Vladimir Valentinovich Kozhevnikov) [16] has become characteristic of the methodology of theoretical and legal science "[17].

In the variety of approaches used in modern science, dialectical-materialistic methodology, from the point of view of V.P. Kokhanovsky, plays an ever-increasing (dominant - Vladimir Valentinovich Kozhevnikov) role [18].

Domestic scientists, in our opinion, quite reasonably declare that today there are no convincing arguments against the use of materialistic dialectics as one of the variants of the theoretical understanding of the world and elements of the methodology of scientific research. As the authors say, "in the modern philosophical market, it is quite competitive" [19]. Vladimir Mikhailovich Syrykh, being a supporter of the Marxist theory of law, writes that in the history of political and legal thought for the last hundred years, it was the Marxist doctrine that was the undisputed leader and has not lost its leading position at the present time, "for there is no other theory capable of fully and consistently responding to complex questions of jurisprudence that other theories cannot reveal "[20]. In his other work, the scientist, referring to the characteristics of the methodological function of dialectical (and historical) materialism, emphasizes that it "... is expressed in the orientation of the cognizing subject to obtain objectively true knowledge, to reveal the ways and means of obtaining such knowledge and the forms of its objectification, presentation. As the general laws of scientific knowledge, the principles of dialectical logic constitute the initial methodological basis for the knowledge of any special, concrete science, show what the path of comprehension of objectively true knowledge should be "[21].

It seems that the position of the American professor Lauren Raymond Graham is a convincing confirmation of the significance of the analyzed method: "If we recognize the legitimacy of raising fundamental questions about the nature of things, then the dialecticalmaterialist approach, scientifically oriented, realistic, materialistic, claims superiority over existing and competing universal systems of thinking, and these claims can be sufficiently substantiated "[22].

Oleg Alexandrovich Puchkov, naming and characterizing the main properties of the theory of state and law in the era of the domination of the communist doctrine mythology, autocentrism, speculativeness, utopianism and orthodoxy, [23] nevertheless further writes that, "... despite the heavy burden of decades imposed archaic political and 
legal provisions ... the science of state and law is now developing. It frees itself from those scientific constructions that do not allow explaining complex phenomena of political and legal reality, looking for new approaches "[23].

Aleksandr Ivanovich Demidov is more skeptical about the process of development of domestic theoretical science, speaking of the retardation (from the Latin retardatio slowing down - Vladimir Valentinovich Kozhevnikov) of its methodology, which, in an effort to preserve the familiar and really explains a lot of the Marxist paradigm of interpreting legal reality, which "... explains legal reality with the help of such categories as class, formationality, economic determination of state-legal phenomena, their superstructure nature and development according to the "laws of dialectics", the identification of revolutionism with fundamentalism, the depth of transformations". Moreover, this methodology \&quot;... coexists with a visible recognition of the need for changes, but within the framework of the usual style of thinking\&quot; [24].

It is the dialectical method that is defined as the main method that allows to reveal the patterns of development of a particular legal phenomenon, [25] used by scientists in the preparation of dissertations for the degree of candidate (doctor) of jurisprudence. Sergei Ivanovich Svyatkin, in his Ph.D. thesis abstract, claims that in his work he was guided by "a dialectical understanding of the process of historical development, based on the recognition of the conditionality of the regularity of events and phenomena in history" [26].

In any case, what many authors draw attention to is that the so-called metaphysical methods of studying state and legal reality do not fit well into the system of other methods, methodology as a whole. For example, Vyacheslav Nikolayevich Zhukov, noting that the experience of the nineteenth and especially the twentieth century showed that far from all philosophical schools were methodologically fruitful for the philosophy of law, argues that "often lawyers artificially, very arbitrarily tried to combine philosophy and jurisprudence, most not so much the possibilities of philosophy in the matter of cognition of law, as its own possibilities in constructing speculative schemes \&quot;, meaning such "strained, invented concepts, built on the basis of phenomenology and existentialism" [17].

As for our attitude to the possibilities of using the potential of another method hermeneutics in jurisprudence, it, like a number of scientists, is quite critical [27]. For example, Vladimir Mikhailovich Syrykh, in our opinion, convincingly showed the futility of hermeneutics as a method of cognition in law [28]. Apparently, and most likely, this circumstance is due to the fact that this method is very rarely included in the system of methods of cognition of law.

Note that even those scholars who pinned certain hopes on legal hermeneutics in terms of research now began to doubt its potential. For example, Ilya Lvovich Chestnov, having named his monograph "Legal Understanding in the Postmodern Era", having analyzed phenomonology, hermeneutics, synergetics, etc. in it, came to the conclusion that these approaches to law as independent have not yet taken place "[29]. In this regard, Igor Yuryevich Kozlikhin quite reasonably notes that the last decade has been characterized by the search for a new paradigm. Increasingly, they are trying to find it outside the law, to attract knowledge developed in the bosom of other sciences to the study of law. This is most clearly manifested in the general theory. The scientist believes that such attempts should be welcomed, but only if they deepen our knowledge about law, and not about the subject of those sciences to which we turn [30]. 


\section{Conclusion}

In conclusion, we note that the belittling of the status of the general theory of state and law at the theoretical level, which impoverishes the education of modern lawyers, leads to the collapse of domestic legal science, which recognized at all stages of its development (pre-revolutionary, Soviet, post-Soviet) the fundamental, methodological nature of the former [31;32]. Moreover, attacks on the theory of state and law gradually turned into a practical plane: the abolition of the state exam in this discipline, a decrease in teaching hours, the refusal of some legal journals (for example, "Modern Law", "Bulletin of St. Petersburg University, etc.) to print scientific articles on general theoretical problems, etc. We believe that such an abnormal situation must be corrected, focusing at the same time on the assertions of the founder of the theory of state and law, Nikolai Mikhailovich Korkunov, that "the general theory of law (and the theory of the state Vladimir Valentinovich Kozhevnikov) is ... the cornerstone of the system of jurisprudence" [33].

\section{References}

[1]. Radko Timofey Nikolaevich, Lazarev Valery Vasilievich, Morozova Lyudmila Aleksandrovna. Theory of State and Law: Textbook), Moscow: Prospect Publishing House, 2012. P. 13.

[2]. Polyakov Andrey Vasilievich, Timoshina Elena Vladimirovna, Romashov Roman Anatolyevich. Theory of state and law at the turn of the century // Legal Science. 2000. Number 3. P.244.

[3]. Roman Anatolyevich Romashov. Theory of State and Law. Short course.- SPb: Peter Publishing House, 2010. Pp.4, 5.

[4]. Evgeny I. Temnov. Method of the theory of state and law // General theory of law and state: textbook / ed. Valery Vasilyevich Lazarev. M .: Publishing house Novy Yurist, 1997.Pp. 22, 23-24.

[5]. Sinyukova Tatyana Vitalievna Legal awareness and legal education // Theory of state and law: textbook / ed. Nikolai Ignatievich Matuzov and Alexander Vasilyevich Malko. M .: Publishing house Yurist. P.615.

[6] Granin Daniil Alexandrovich. The secret sign of Petersburg. SPb: Publishing house "Logos", 2000. Pp.14, 174, 241.

[7]. Bayniyazov Rustam Suleimanovich. Philosophy of Legal Awareness // Jurisprudence. 2001. No. 5. P.19.

[8]. Ekimov Anisim Ivanovich. Political interests and legal science // State and law. 1996. No. 12. Pp.3-4.

[9]. A short philosophical dictionary / ed. Mark Moiseevich Rosenthal and Pavel Fedorovich Yudin. M .: Gospolizdat, 1941. P.47

[10]. Bryzgalov Andrey Ivanovich. On some theoretical and methodological problems of legal science at the present stage // State and Law. 2004. No. 4. P.17.

[11]. Evgeny Ivanovich Temnov. On the deideologization of methodological approaches in historical-political and state-legal research // State and Law, 1992, No. 3. P. 75.

[12]. Martyshin Orest Vladimirovich. About the concept of the textbook of the theory of state and law // State and law. 2002. No. 8. Pp. 66, 67.

[13]. Chetvernin Vladimir Alexandrovich. The concept of law and state. Introduction to the course of the theory of law and state. M .: Publishing house of the Institute of State and Law of the Russian Academy of Sciences, 2003. P.111. 
[14]. Baranov P.P., Vereshchagin Victor Yurievich, Kurbatov Vladimir Ivanovich, Ovchinnikov Alexey Igorievich. Philosophy of law: textbook. Rostov n / a: Phoenix Publishing House, 2004. P.3.

[15]. Korelsky Victor Mikhailovich. Methods of the theory of state and law // Theory of state and law: textbook / ed. Victor Mikhailovich Korelsky, Victor Dmitrievich Perevalov. M. Publishing house INFRA-M, 2000. Pp.12-13.

[16]. Kozhevnikov Vladimir Valentinovich. On the question of the criteria for the truth of knowledge about the state and law // Modern Law. 2014. No. 2. Pp.12-16.

[17]. Zhukov Vyacheslav Nikolaevich. Philosophy of law: textbook. -M .: Publishing house World of Philosophy, Algorithm, 2019.Pp.37, 39.

[18]. Kokhanovsky Valery Pavlovich, Przhlensky Vladimir Igorievich, Sergodeeva Elena Alexandrovna. Philosophy of law: textbook. M.-Rostov n / a: Publishing house of ICC "Mart" 2005. Pp.127-128.

[19]. B'aranov Vladimir Mikhailovich, Pershin Victor Borisovich, Baranova Marina Vladimirovna. The place and role of the method of materialistic dialectics in legal research // Philosophy of law. 2007. No. 3. P.10.

[20]. Syrykh Vladimir Mikhailovich. Theory of state and law: textbook. Moscow: Yustitsinform Publishing House, 2001. P.478.

[21]. Syrykh Vladimir Mikhailovich. Logical foundations of the general theory of law in 2 volumes. T.1 Elemental composition. M.: Publishing house of ZAO "Yustitsinform", 2004.P. 188.

[22]. Graham Lauren Raymond. Natural science, philosophy and the science of human behavior in the Soviet Union. M .: Politizdat, 1991.P. 15.

[23]. Puchkov Oleg Alexandrovich. Theory of State and Law: Problems and Prospects // Jurisprudence. 2001. No. 6. Pp.5, 6-7.

[24]. Demidov Alexander Ivanovich. On the methodological situation in jurisprudence // Jurisprudence. 2001 No. 4. P.16.

[25]. Petrov Alexey Alexandrovich. Decisions of the Constitutional Court of the Russian Federation in the doctrine and practice of constitutional justice. // author. ... dis.doc. jurid. sciences. Omsk, 2019. P.9.

[26]. Svyatkin Sergei Ivanovich. Soviet advocacy and territorial advocacy associations in Western Siberia in the 1960s and early 1990s. // author. dis. ... Cand. jurid. Sciences Omsk, 2020. P. 14.

[27]. Vlasenko Nikolai Alexandrovich. Methodological problems of modern theory of law // Journal of Russian law. 2019. No. 4. P.8.

[28]. Syrykh Vladimir Mikhailovich. The hermeneutic circle as a methodological dead end // Modern research methods in jurisprudence / ed. Nikolai Ignatievich Matuzov, Alexander Vasilyevich Malko. Saratov: Publishing house SUI of the Ministry of Internal Affairs of Russia, 2007. Pp. 193-235.

[29]. Chestnov Ilya Lvovich. Legal understanding in the postmodern era: monograph.$\mathrm{SPb}$ : Publishing house of St. Petersburg Institute of foreign economic relations, economics and law, 2002. P.272. [thirty]. Kozlikhin Igor Yurievich. On nontraditional approaches to law // Jurisprudence. 2006. No. 1. P.31

[31]. Kozhevnikov Vladimir Valentinovich. General theory of state and law: in defense of basic, methodological science // Bulletin of the Omsk State. un-that. Series \&quot; Right\&quot;. 2018. No. 4. Pp.72-79.

[32]. Kozhevnikov Vladimir Valentinovich. General theory of law: history and modernity (to the 110th anniversary of Andrey Ivanovich Denisov) / otv. ed. Mikhail 
Nikolaevich Marchenko. Moscow: Prospect Publishing House, 2018- 416 p. // State and Law. 2019. No.11. Pp.155-156.

[33]. Radko Timofey Nikolaevich. Reader on the theory of state and law. Moscow: Prospect Publishing House, 2009. P.217. 